Andrzej Dakowicz

Uniwersytet $w$ Biatymstoku

\title{
Małżonkowie transgresyjni i zachowawczy - psychologiczna analiza szansy powodzenia i ryzyka rozpadu związku małżeńskiego
}

\section{TRANSGRESSIVE AND PROTECTIVE SPOUSES - PSYCHOLOGICAL ANALYSIS THE CHANCE OF SUCCESS AND RISKS OF BREAKDOWN MARRIAGE}

According to J. Kozielecki's personality network theory chosen or constructed tools operationalizing five psychons: cognitive, instrumental, motivational, emotional and personal. 100 couples were examined, from which isolated groups of 30 spouses of high level of transgression (transgressive) and 30 spouses of low level transgression (protective). Transgressive spouses are characterized wide knowledge about each in the sphere of the task force, their motivation for action is based primarily on cognitive needs and they have a higher awareness of personal beliefs. Transgressive husbands have a positive affective shift. Potential bring to the interpersonal relations by the transgressive spouses creates a favorable climate, which increases the likelihood of building a stable relationships satisfying both spouses.

Key words: psychotransgressionism, network theory of personality, transgressive and protective spouses, success of marriage, risk of divorce. 


\section{Wprowadzenie}

Pełny rozwój człowieka w największym stopniu oparty jest na osobistym doświadczeniu szczególnie pierwszych lat życia spędzonych w rodzinie ${ }^{1}$. Stabilne środowisko rodzinne daje możliwości na zaspokojenie podstawowych potrzeb i otwiera droge ku realizacji potencjałów ukrytych we wszystkich członkach rodziny ${ }^{2}$. Niestety dezintegracja dotychczasowych form życia małżeńsko-rodzinnego, zmiany w pozycji poszczególnych członków rodziny ${ }^{3}$, jak również coraz liczniejsze alternatywy w stosunku do małżeństwa, jako trwałej relacji między mężczyzną i kobietą̨, sprawiają, że znaczna część małżeństw rozpada się doprowadzając w konsekwencji do poważnych zranień psychicznych wszystkich członków rodziny ${ }^{5}$. Mimo tak niekorzystnych przemian okazuje się, że młodzież reprezentująca różne kultury (badano młodzież w takich krajach, jak: Polska, Niemcy, Hiszpania, Korea Południowa i Litwa) wyraźnie wskazuje, że w nowoczesnym społeczeństwie małżeństwo, jako akceptowana społecznie forma współżycia pary osób odmiennej płci, ma i będzie miało duże znaczenie $^{6}$. Podobnie, realizowane badania młodzieży w nieco innych krajach: Chile, Hiszpania, Korea Południowa, Litwa, Niemcy, Polska i Ukraina, wykazują istotną preferencję wartości tradycyjnej - rodziny („żyć szczęśliwie w rodzinie”, „założyć własną rodzinę”)"

Wobec takiej sytuacji bardzo ważne staje się poszukiwanie czynników, które mogą mieć znaczenie w tworzeniu satysfakcjonujących małżonków relacji. Badacze wykorzystując różne koncepcje teoretyczne próbują wyjaśniać zachodzące procesy i określić najważniejsze

1 M. Jeziorański, D. Opozda, A. Rynio (red.), Rodzina przestrzenia rozwoju osoby. Perspektywa pedagogiczna, Lublin 2012.

M. Braun-Gałkowska, Psychologia domowa, Lublin 2008, s. 23-27; eadem, Nie wszystkie kwiaty zakwitaja razem. Kilka myśli o starości, Lublin 2015.

F. Adamski, Rodzina. Wymiar społeczno-kulturowy, Kraków 2002, s. 179.

D. Jabłoński, L. Ostasz, Zarys wiedzy o rodzinie, matżeństwie, kohabitacji i konkubinacie. Perspektywa antropologii kulturowej i ogólnej, Olsztyn 2001. berska (red.), Psychologia rodziny, Warszawa 2014, s. 459-481. dycja a nowoczesnościa, Lublin 2009, s. 77. 
czynniki wpływające na jakość relacji małżeńskiej ${ }^{8}$. Wydają się być szczególnie obiecujące poszukiwania oparte na nowych, coraz lepiej opracowanych teoretycznie, koncepcjach ludzkiej psychiki. Jednym z przykładów syntetycznego ujęcia złożonej struktury ludzkiej psychiki, dającym możliwość uchwycenia dynamiki i wzajemnego wpływu w bliskich relacjach interpersonalnych jest opracowany przez Józefa Kozieleckiego psychotransgresjonizm ${ }^{9}$.

\section{Transgresyjne ujęcie powodzenia małżeństwa}

Psychotransgresjonizm skoncentrowany jest na rozwoju osobowości i stylu zachowania się jednostki. Indywidualność każdego z nas wyrażana jest przez specyficzną sieć pięciu psychonów: poznawczego - „wiem, że”, instrumentalnego - „umiem jak”, motywacyjnego „dążę do”, emocjonalnego - „czuję, że” i osobistego - „kim jestem”10. Człowiek jako sprawca, wpływa zarówno na dziedzictwo kulturowe, jak i na osobiste przystosowanie się do środowiska ekosocjokulturowego $^{11}$, poprzez podejmowanie działań ochronnych (paliatywnych, zachowawczych) i transgresyjnych. W przypadku relacji małżeńskiej działania ochronne związane są z podejmowaniem różnego rodzaju obowiązków domowych, unikaniem zadrażnień, nieporozumień czy konfliktów. Mąż i żona robią to, co do nich należy, kiedy pojawiają się trudności próbują je przezwyciężyć, aby przywrócić poprzedni stan względnej równowagi i spokoju. Działania transgresyjne polegają na intencjonalnym wychodzeniu poza codzienną rzeczywistość małżeńską i robieniu rzeczy nowych lub w nowy sposób z zamiarem polepszenia, pogłębienia wzajemnej relacji, która ma stać się dla małżonków bardziej satysfakcjonująca ${ }^{12}$. Im częściej małżonkowie podejmują działania transgresyjne, tym więcej mają okazji, aby poznać siebie, współmałżonka i doświadczyć radości bycia wspólnotą, w której oboje

$8 \quad$ M.Braun-Gałkowska, Psychologiczna analiza systemów rodzinnych osóbzadowolonych i niezadowolonych z matżeństwa, Lublin 1992; J. Rostowski, T. Rostowska, Mał̇̇eństwo i miłość. Kontekst psychologiczny i neuropsychologiczny, Warszawa 2014.

J. Kozielecki, Psychotransgresjonizm. Nowy kierunek psychologii, Warszawa 2007.

Ibidem, s. 123-141.

11 E. Aranowska, M. Goszczyńska (red.), Człowiek wobec wyzwań i dylematów wspótczesności, Warszawa 2006.

12 A. Dakowicz, Marital success from the perspective of Kozielecki's transgression model, ,Studies in Logic, Grammar and Rhetoric. Cognitive Systems” 40(2015), s. 321-333. 
chcą uczestniczyć. „Powodzenie małżeństwa jest efektem specyficznej formy transgresji podejmowanej w rzeczywistości życia małżeńskiego przez oboje małżonków. Polega ona na rozpoznawaniu pojawiających się trudności, szukaniu ich przyczyn i podejmowaniu wspólnych działań zmierzających do ich przezwyciężenia" ${ }^{13}$. Ponieważ podejmowanie działań transgresyjnych korzystniej wpływa na rzeczywistość życia małżeńskiego i bardziej odpowiada istocie małżeństwa, postawiono pytanie badawcze dotyczące bliższej charakterystyki zawartości psychonów małżonków transgresyjnych i zachowawczych. Pomocą w uzyskaniu odpowiedzi na postawione pytanie będzie porównanie wyników badań grup małżonków, którzy różnią się między sobą tylko zmienną niezależną, a więc poziomem transgresji.

\section{Metoda badawcza}

W oparciu o koncepcję psychotransgresjonizmu zoperacjonalizowano pięć psychonów ${ }^{14}$ dobierając lub tworząc nowe narzędzia badawcze. Psychon poznawczy zbadany został przy użyciu Kwestionariusza Wiedzy o Współmałżonku ${ }^{15}$. Obejmuje on cztery sfery: ogólną, uczuciową, zadaniową i wartości. Sformułowano 10 pytań otwartych do sfery ogólnej, np. „Imiona babci i dziadka ze strony ojca” oraz po 10 pytań zamkniętych z możliwością odpowiedzi „tak” lub „nie” do sfery uczuciowej, np. „Często mówi mi o tym, co czuje i przeżywa”, do sfery zadaniowej, np. „Potrafi dobrze zaplanować większość swoich działan”, do sfery wartości, np. „Mój współmałżonek bardziej koncentruje się na życiu zawodowym, niż rodzinnym". Badani małżonkowie odpowiadają na pytania z zakresu każdej ze sfer na temat współmałżonka, a później odpowiadają na te same pytania odnośnie siebie. Porównując obie listy można stwierdzić, które odpowiedzi pokrywają się, co w konsekwencji pozwala określić poziom wiedzy na temat współmałżonka. Wynik maksymalny kwestionariusza to 40 (gdy wszystkie odpowiedzi pokrywają się), a minimalny to 0 (gdy żadna z odpowiedzi nie pokrywa się).

Do zbadania psychonu instrumentalnego wykorzystano skalę inteligencji ogólnej APIS-Z, która daje możliwość określenia następujących zdolności badanych: abstrakcyjno-logicznych (klasyfikacja

13 A. Dakowicz, Powodzenie matżeństwa. Uwarunkowania psychologiczne w perspektywie transgresyjnego modelu Józefa Kozieleckiego, Białystok 2014, s. 131. J. Kozielecki, Psychotransgresjonizm..., op. cit., s. 124-137.

15 A. Dakowicz, Psychologiczna analiza matżonków o wysokim i niskim poziomie transgresji, [w:] T. Rostowska, A. Lewandowska-Walter (red.), Matżeństwo i rodzicielstwo a zdrowie, Toruń 2012, s. 79-101. 
i przekształcenia liczb), werbalnych (synonimy i nowe słowa), wzrokowo-przestrzennych (kwadraty i klocki) oraz społecznych (zachowania i historyjki ${ }^{16}$.

Psychon motywacyjny zbadany został przy wykorzystaniu Testu Indywidualnych Potrzeb ${ }^{17}$, gdzie istnieje możliwość określenia preferencji potrzeb: witalnych, poznawczych, społecznych i osobistych ${ }^{18}$. Badani w grupach składających się z czterech rodzajów potrzeb mieli do rozdysponowania cztery punkty, przypisując najwięcej punktów temu twierdzeniu, które wyrażało w największym stopniu ich dążenia, np. „Chciałbym więcej odpoczywać” (potrzeba witalna); „Chciałbym bardziej rozwijać swoje zainteresowania” (potrzeba poznawcza); „Chciałbym czuć się bezpieczniej w kontaktach z innymi” (potrzeba społeczna); „Chciałbym bardziej czuć sens swojego życia” (potrzeba osobista).

Psychon emocjonalny zdiagnozowany został przy użyciu dyferencjału semantycznego, gdzie badani w stosunku do dwunastu pojęć: po trzy pojęcia egzystencjalne, np. zdrowie, trzy pojęcia związane z rodziną pochodzenia, np. matka, trzy pojęcia związane z rodziną aktualną, np. dziecko i trzy pojęcia związane z pracą, np. wynagrodzenie wyrażają swoje konotacje emocjonalne ${ }^{19}$.

Psychon osobisty zbadany został przy użyciu Testu Świadomych Osobistych Przekonań ${ }^{20}$, gdzie badani na 5-cio stopniowej skali: 1 bardzo rzadko, 2 - rzadko, 3 - czasem, 4 - często, 5 - bardzo często wyrażają swoje przekonania, co do siedmiu rodzajów poczuć stanowiących istotę psychonu osobistego, np. „Mam poczucie, że jestem sprawcą podejmowanych przeze mnie działań".

Poziom transgresji badanych małżonków określono wykorzystując Skalę Transgresji opracowaną w oparciu o koncepcję psychotransgresjonizmu Kozieleckiego. Daje ona możliwość ilościowego oszacowania wielkości transgresji badanej osoby za pomocą wymiernie opisanych rezultatów działań transgresyjnych, ich częstotliwości, uczestnictwa w realizacji celów transgresyjnych, względnie satysfakcji przeżywanej w związku z zachowaniami transgresyjnymi. Opracowane wskaźniki psychometryczne i wyodrębnione cztery czynniki: nastawienie na dominowanie nad innymi, innowacyjność wykorzystywana

16 A. Matczak, A. Jaworowska, A. Ciechanowicz, J. Stańczak, Bateria testów APIS-Z. Podręcznik, Warszawa 2006.

17

A. Dakowicz, Potrzeby indywidualne matżonkówzadowolonychiniezadowolonych ze swojego związku, „Edukacja. Studia, badania, innowacje” 3(2011), s. 99-105.

B. Reddin, Testy dla menedżerów stawiajacych na efektywność, Warszawa 1993.

E. Babbie, Badania spoteczne w praktyce, Warszawa 2004.

A. Dakowicz, Psychologiczna analiza matżonków..., op. cit. 
w projektowaniu nowych rozwiązań, motywacja do wzbogacania kompetencji i odwaga w podejmowaniu nowych zadań pozwalają określić Skalę jako dobre narzędzie do pomiaru transgresyjności ${ }^{21}$.

Badaniami objęto 100 par małżeńskich, będących w pierwszym formalnym związku małżeńskim z minimum 5-letnim stażem, posiadających wykształcenie średnie lub wyższe, aktywnych zawodowo i pełniących funkcje rodzicielskie. Na podstawie wyniku uzyskanego w Skali Transgresji ${ }^{22}$ wyodrębniono żony transgresyjne (średni wynik 60,2; średnia wieku 34,3 lat), żony zachowawcze (średni wynik 43,8; średnia wieku 37,6 lat), mężów transgresyjnych (średni wynik 66,2; średnia wieku 35,4 lat) i mężów zachowawczych (średni wynik 47,6; średnia wieku 39,4 lat).

Opracowując uzyskane wyniki wykorzystano program komputerowy SPSS 21.0 PL for Windows, za pomocą którego obliczono wartość testu t-Studenta dla porównywanych grup małżonków o wysokim i niskim poziomie transgresji ${ }^{23}$.

\section{Wyniki}

W sferze wiedzy o mężu: ogólnej, uczuciowej i wartości żony transgresyjne nie różnią się w sposób istotny statystycznie od żon zachowawczych. Żony transgresyjne posiadają znacznie wyższą wiedzę na temat swoich mężów w zakresie sfery zadaniowej $-t(58)=2,85 ; p<0,006$.

Tabela 1. Wiedza o mężu żon o wysokim i niskim poziomie transgresji

\begin{tabular}{|c|c|c|c|c|c|c|}
\hline \multirow{2}{*}{$\begin{array}{c}\text { Sfery } \\
\text { wiedzy } \\
\text { o mężu }\end{array}$} & \multicolumn{2}{|c|}{$\begin{array}{c}\text { Żony } \\
\text { transgresyjne } \\
(\mathrm{n}=\mathbf{3 0})\end{array}$} & \multicolumn{2}{|c|}{$\begin{array}{c}\dot{\text { Żony }} \\
\text { zachowawcze } \\
(\mathbf{n}=\mathbf{3 0})\end{array}$} & \multicolumn{2}{|c|}{ Istotność różnic } \\
\hline & MI & $\mathbf{s}$ & M & $\mathbf{s}$ & $\mathbf{t}$ & $\mathbf{p}<$ \\
\hline Ogólna & 6,10 & 1,45 & 6,13 & 1,74 & $-0,81$ & n.i. \\
\hline Uczuciowa & 7,37 & 1,52 & 6,77 & 1,87 & 1,36 & n.i. \\
\hline Zadaniowa & 7,33 & 1,63 & 6,10 & 1,73 & 2,85 & 0,006 \\
\hline Wartości & 8,17 & 1,53 & 8,17 & 1,60 & 0,00 & n.i. \\
\hline Razem & 28,97 & 2,75 & 27,17 & 3,82 & 2,10 & 0,04 \\
\hline
\end{tabular}

$21 \quad$ R. Studenski, Skłonność do ryzyka a zachowania transgresyjne, [w:] M. Goszczyńska, R. Studenski (red.), Psychologia zachowań ryzykownych. Koncepcje, badania, praktyka, Warszawa 2006, s. 128-142.

22 Ibidem.

23 S. Bedyńska, M. Cypryańska (red.), Statystyczny drogowskaz 1. Praktyczne wprowadzenie do wnioskowania statystycznego, Warszawa 2013. 
Podobnie w przypadku badanych mężów transgresyjnych ich wiedza na temat żon w sferze ogólnej, uczuciowej i wartości nie różni się w sposób istotny statystycznie. Mężowie transgresyjni posiadają znacznie wyższą wiedzę na temat swoich żon w zakresie sfery zadaniowej $-t(58)=2,77 ; p<0,007$.

Tabela 2. Wiedza o żonie mężów o wysokim i niskim poziomie transgresji

\begin{tabular}{|l|c|c|c|c|c|c|}
\hline \multirow{2}{*}{$\begin{array}{c}\text { Sfery } \\
\text { wiedzy } \\
\text { o żonie }\end{array}$} & \multicolumn{2}{c|}{$\begin{array}{c}\text { Mężowie } \\
\text { transgresyjni } \\
(\mathbf{n = 3 0 )}\end{array}$} & \multicolumn{2}{c|}{$\begin{array}{c}\text { Mężowie } \\
\text { zachowawczy } \\
(\mathbf{n = 3 0 )}\end{array}$} & \multicolumn{2}{c|}{ Istotność różnic } \\
\cline { 2 - 7 } & $\mathbf{M}$ & $\mathbf{S}$ & $\mathbf{M}$ & $\mathbf{S}$ & $\mathbf{t}$ & $\mathbf{p}<$ \\
\hline Ogólna & 5,23 & 1,61 & 4,97 & 1,71 & 0,62 & n.i. \\
\hline Uczuciowa & 6,93 & 1,53 & 6,70 & 1,49 & 0,60 & n.i. \\
\hline Zadaniowa & 7,20 & 1,32 & 5,90 & 2,20 & 2,77 & 0,007 \\
\hline Wartości & 8,53 & 1,36 & 8,67 & 1,24 & $-0,40$ & n.i. \\
\hline Razem & 27,90 & 2,75 & 26,23 & 3,83 & 1,94 & n.i. \\
\hline
\end{tabular}

Wśród badanych czterech typów zdolności żony transgresyjne uzyskały nieco wyższe wyniki w zakresie zdolności abstrakcyjno-logicznych i społecznych. Natomiast żony zachowawcze nieco wyższe wyniki w zakresie zdolności werbalnych i wzrokowo-przestrzennych. Nie są to jednak różnice istotne statystycznie.

Tabela 3. Poziom zdolności żon o wysokim i niskim poziomie transgresji

\begin{tabular}{|l|c|c|c|c|c|c|}
\hline \multirow{2}{*}{$\begin{array}{c}\text { Typy } \\
\text { zdolności }\end{array}$} & \multicolumn{2}{|c|}{$\begin{array}{c}\text { Żony } \\
\text { transgresyjne } \\
(\mathbf{n = 3 0 )}\end{array}$} & \multicolumn{2}{c|}{$\begin{array}{c}\text { 吕ony } \\
\text { zachowawcze } \\
(\mathbf{n = 3 0 )}\end{array}$} & \multicolumn{2}{c|}{ Istotność różnic } \\
\cline { 2 - 7 } & $\mathbf{M}$ & $\mathbf{s}$ & $\mathbf{M}$ & $\mathbf{~}$ & $\mathbf{t}$ & $\mathbf{p}<$ \\
\hline $\begin{array}{l}\text { Abstrakcyjno- } \\
\text { logiczne }\end{array}$ & 7,47 & 2,40 & 6,83 & 3,17 & 0,87 & n.i. \\
\hline Werbalne & 5,23 & 2,97 & 5,43 & 2,69 & $-0,27$ & n.i. \\
\hline $\begin{array}{l}\text { Wzrokowo- } \\
\text { przestrzenne }\end{array}$ & 7,70 & 2,57 & 7,83 & 3,37 & $-0,17$ & n.i. \\
\hline Społeczne & 9,07 & 2,62 & 8,00 & 2,74 & 1,54 & n.i. \\
\hline Razem & 29,47 & 7,95 & 28,10 & 9,49 & 0,60 & n.i. \\
\hline
\end{tabular}

Mężowie transgresyjni uzyskali nieco wyższe wyniki w zakresie zdolności abstrakcyjno-logicznych, wzrokowo-przestrzennych i społecznych. Natomiast mężowie zachowawczy uzyskali nieco wyższe 
wyniki w zakresie zdolności werbalnych, nie są to jednak różnice istotne statystycznie.

Tabela 4. Poziom zdolności mężów o wysokim i niskim poziomie transgresji

\begin{tabular}{|l|c|c|c|c|c|c|}
\hline \multirow{2}{*}{\begin{tabular}{c}
\multirow{2}{*}{$\begin{array}{c}\text { Typy } \\
\text { zdolności }\end{array}$} \\
\cline { 2 - 7 }
\end{tabular}} & \multicolumn{2}{c|}{$\begin{array}{c}\text { Mężowie } \\
\text { transgresyjni } \\
(\mathbf{n = 3 0 )}\end{array}$} & \multicolumn{2}{c|}{$\begin{array}{c}\text { Mężowie } \\
\text { zachowawczy } \\
(\mathbf{n = 3 0 )}\end{array}$} & \multicolumn{2}{c|}{ Istotność różnic } \\
\cline { 2 - 7 } $\begin{array}{l}\text { Abstrakcyjno- } \\
\text { logiczne }\end{array}$ & 8,63 & 3,02 & 8,20 & 2,32 & 0,62 & n.i. \\
\hline Werbalne & 5,87 & 3,23 & 6,10 & 2,59 & $-0,31$ & n.i. \\
\hline $\begin{array}{l}\text { Wzrokowo- } \\
\text { przestrzenne }\end{array}$ & 10,13 & 2,85 & 9,80 & 2,67 & 0,47 & n.i. \\
\hline Społeczne & 9,03 & 2,91 & 8,43 & 2,27 & 0,89 & n.i. \\
\hline Razem & 32,33 & 10,58 & 32,53 & 6,96 & $-0,09$ & n.i. \\
\hline
\end{tabular}

Spośród potrzeb indywidualnych żony transgresyjne preferują potrzeby osobiste, następnie poznawcze, społeczne i na końcu witalne. Podobnie żony zachowawcze w pierwszej kolejności preferują potrzeby osobiste, ale w dalszej kolejności występują u nich potrzeby witalne, społeczne i na końcu poznawcze. Pomiędzy badanymi grupami żon nie zarejestrowano różnic istotnych statystycznie.

Tabela 5. Potrzeby indywidualne żon o wysokim i niskim poziomie transgresji

\begin{tabular}{|c|c|c|c|c|c|c|}
\hline \multirow[t]{2}{*}{$\begin{array}{l}\text { Rodzaje } \\
\text { potrzeb }\end{array}$} & \multicolumn{2}{|c|}{$\begin{array}{c}\text { Żony } \\
\text { transgresyjne } \\
(\mathbf{n}=30)\end{array}$} & \multicolumn{2}{|c|}{$\begin{array}{c}\dot{\text { Żony }} \\
\text { zachowawcze } \\
(\mathbf{n}=\mathbf{3 0})\end{array}$} & \multicolumn{2}{|c|}{ Istotność różnic } \\
\hline & $\mathbf{M}$ & $\mathbf{s}$ & M & $\mathbf{s}$ & $\mathbf{t}$ & $\mathbf{p}<$ \\
\hline Witalne & 11,97 & 6,14 & 13,33 & 5,70 & $-0,89$ & n.i. \\
\hline Poznawcze & 14,57 & 6,52 & 12,93 & 6,99 & 0,94 & n.i. \\
\hline Społeczne & 13,90 & 4,70 & 13,07 & 5,08 & 0,66 & n.i. \\
\hline Osobiste & 15,57 & 6,91 & 16,67 & 7,62 & $-0,59$ & n.i. \\
\hline
\end{tabular}

Mężowie transgresyjni w największym stopniu preferują potrzeby poznawcze, następnie społeczne, witalne i na końcu osobiste. Mężowie zachowawczy w największym stopniu preferują potrzeby osobiste, następnie społeczne, witalne i na końcu poznawcze. Mężowie transgresyjni charakteryzują się zdecydowanie silniejszymi potrzebami poznawczymi $-t(58)=3,33 ; p<0,001$ oraz zdecydowanie 
słabszymi potrzebami osobistymi $-t(58)=-2,67 ; p<0,01$, niż mężowie zachowawczy.

Tabela 6. Potrzeby indywidualne mężów o wysokim i niskim poziomie transgresji

\begin{tabular}{|l|c|c|c|c|c|c|}
\hline \multirow{2}{*}{$\begin{array}{c}\text { Rodzaje } \\
\text { potrzeb }\end{array}$} & \multicolumn{2}{c|}{$\begin{array}{c}\text { Mężowie } \\
\text { transgresyjni } \\
(\mathbf{n = 3 0 )}\end{array}$} & \multicolumn{2}{c|}{$\begin{array}{c}\text { Mężowie } \\
\text { zachowawczy } \\
(\mathbf{n = 3 0 )}\end{array}$} & \multicolumn{2}{c|}{ Istotność różnic } \\
\cline { 2 - 7 } & $\mathbf{M}$ & $\mathbf{S}$ & $\mathbf{M}$ & $\mathbf{S}$ & $\mathbf{t}$ & p< \\
\hline Witalne & 13,37 & 6,19 & 12,90 & 4,25 & 0,34 & n.i. \\
\hline Poznawcze & 16,73 & 6,66 & 11,67 & 4,98 & 3,33 & 0,001 \\
\hline Społeczne & 13,43 & 6,08 & 15,17 & 4,79 & $-1,23$ & n.i. \\
\hline Osobiste & 12,47 & 5,73 & 16,27 & 5,28 & $-2,67$ & 0,01 \\
\hline
\end{tabular}

Rozkład konotacji emocjonalnych żon transgresyjnych i zachowawczych wygląda podobnie. Dominują dodatnie, następnie neutralne i ujemne. Pomiędzy badanymi grupami żon nie zarejestrowano różnic istotnych statystycznie.

Tabela 7. Konotacje emocjonalne żon o wysokim i niskim poziomie transgresji

\begin{tabular}{|l|c|c|c|c|c|c|}
\hline \multirow{2}{*}{$\begin{array}{c}\text { Rodzaje } \\
\text { konotacji }\end{array}$} & \multicolumn{2}{|c|}{$\begin{array}{c}\text { Żony } \\
\text { transgresyjne } \\
(\mathbf{n = 3 0 )}\end{array}$} & \multicolumn{2}{c|}{$\begin{array}{c}\text { 吕ony } \\
\text { zachowawcze } \\
(\mathbf{n = 3 0 )}\end{array}$} & \multicolumn{2}{c|}{ Istotność różnic } \\
\cline { 2 - 7 } & $\mathbf{M}$ & $\mathbf{S}$ & $\mathbf{M}$ & $\mathbf{S}$ & $\mathbf{t}$ & $\mathbf{p}<$ \\
\hline Dodatnie & 38,80 & 6,32 & 36,97 & 7,60 & 1,02 & n.i. \\
\hline Neutralne & 5,37 & 4,25 & 6,03 & 6,00 & $-0,50$ & n.i. \\
\hline Ujemne & 3,83 & 3,94 & 5,00 & 4,23 & $-1,10$ & n.i. \\
\hline
\end{tabular}

Podobnie jak w przypadku badanych żon, mężowie o wysokim i niskim poziomie transgresji mają najwięcej konotacji emocjonalnych dodatnich, znacznie mniej neutralnych i najmniej ujemnych. Między badanymi grupami mężów wystąpiła różnica istotna statystycznie odnośnie konotacji dodatnich. Mężowie transgresyjni przejawiają znacznie więcej odniesień emocjonalnych pozytywnych $-t(58)=2,60$; $p<0,012$, niż mężowie zachowawczy. 
Tabela 8. Konotacje emocjonalne mężów o wysokim i niskim poziomie transgresji

\begin{tabular}{|l|c|c|c|c|c|c|}
\hline \multirow{2}{*}{$\begin{array}{c}\text { Rodzaje } \\
\text { konotacji }\end{array}$} & \multicolumn{2}{|c|}{$\begin{array}{c}\text { Mężowie } \\
\text { transgresyjni } \\
(\mathbf{n = 3 0 )}\end{array}$} & \multicolumn{2}{c|}{$\begin{array}{c}\text { Mężowie } \\
\text { zachowawczy } \\
(\mathbf{n = 3 0 )}\end{array}$} & \multicolumn{2}{c|}{ Istotność różnic } \\
\cline { 2 - 7 } & $\mathbf{M}$ & $\mathbf{s}$ & $\mathbf{M}$ & $\mathbf{s}$ & $\mathbf{t}$ & $\mathbf{p}<$ \\
\hline Dodatnie & 41,27 & 5,79 & 37,30 & 6,00 & 2,60 & 0,012 \\
\hline Neutralne & 4,87 & 5,86 & 6,93 & 4,73 & $-1,50$ & n.i. \\
\hline Ujemne & 2,20 & 2,89 & 3,87 & 3,73 & $-1,93$ & n.i. \\
\hline
\end{tabular}

Żony o wysokim i niskim poziomie transgresji istotnie różnią się między sobą odnośnie świadomych osobistych przekonań. Na siedem rodzajów przekonań, w trzech, żony transgresyjne uzyskały wyniki znacznie wyższe, niż żony zachowawcze. W pozostałych czterech przekonaniach wyniki żon transgresyjnych są nieco wyższe, niż wyniki żon zachowawczych, lecz nie osiągnęły poziomu istotności statystycznej. Żony o wysokim poziomie transgresji charakteryzują się wysokim poczuciem sprawstwa podejmowanych przez siebie działań - $t(58)$ $=2,28 ; p<0,026$, bardziej akceptują świat w całości, łącznie z sobą $-t(58)=2,33 ; p<0,039$ i mają silniejsze poczucie, że są niepodzielną całością $-t(58)=1,43 ; p<0,023$.

Tabela 9. Świadome osobiste przekonania żon o wysokim i niskim poziomie transgresji

\begin{tabular}{|l|c|c|c|c|c|c|}
\hline \multirow{2}{*}{ Rodzaje przekonań } & \multicolumn{2}{c|}{$\begin{array}{c}\text { Żony } \\
\text { transgresyjne } \\
(\mathbf{n = 3 0 )}\end{array}$} & \multicolumn{2}{c|}{$\begin{array}{c}\text { Żony } \\
\text { zachowawcze } \\
(\mathbf{n = 3 0 )}\end{array}$} & \multicolumn{2}{c|}{$\begin{array}{c}\text { Istotnośćc } \\
\text { różnic }\end{array}$} \\
\cline { 2 - 7 } & $\mathbf{M}$ & $\mathbf{S}$ & $\mathbf{M}$ & $\mathbf{~}$ & $\mathbf{t}$ & $\mathbf{p}<$ \\
\hline 1. Jestem osobą & 4,47 & 0,86 & 4,07 & 0,87 & 1,79 & n.i. \\
\hline $\begin{array}{l}\text { 2. Poczucie własnego } \\
\text { istnienia }\end{array}$ & 4,60 & 0,50 & 4,33 & 0,76 & 1,61 & n.i. \\
\hline $\begin{array}{l}\text { 3. Jestem sprawcą } \\
\text { podejmowanych przeze } \\
\text { mnie działań }\end{array}$ & 4,43 & 0,63 & 4,00 & 0,83 & 2,28 & 0,026 \\
\hline $\begin{array}{l}\text { 4. Akceptuję świat } \\
\text { w całości, łącznie } \\
\text { z własną osobą }\end{array}$ & 4,20 & 0,76 & 3,73 & 0,94 & 2,33 & 0,039 \\
\hline $\begin{array}{l}\text { 5. Poczucie, że jestem } \\
\text { niepodzielną całością }\end{array}$ & 4,20 & 0,71 & 3,67 & 1,03 & 1,43 & 0,023 \\
\hline $\begin{array}{l}\text { 6. Poczucie, że przez całe } \\
\text { życie jestem sobą }\end{array}$ & 4,27 & 0,78 & 4,07 & 0,83 & 0,96 & n.i. \\
\hline
\end{tabular}




\begin{tabular}{|l|c|c|c|c|c|c|}
\hline \multirow{2}{*}{ Rodzaje przekonań } & \multicolumn{2}{|c|}{$\begin{array}{c}\text { Żony } \\
\text { transgresyjne } \\
(\mathbf{n = 3 0 )}\end{array}$} & $\begin{array}{c}\text { 吕ony } \\
\text { zachowawcze } \\
(\mathbf{n = 3 0})\end{array}$ & \multicolumn{2}{c|}{$\begin{array}{c}\text { Istotność } \\
\text { różnic }\end{array}$} \\
\cline { 2 - 7 } & $\mathbf{M}$ & $\mathbf{s}$ & $\mathbf{M}$ & $\mathbf{s}$ & $\mathbf{t}$ & $\mathbf{p}<$ \\
\hline $\begin{array}{l}\text { 7. Jestem różnym } \\
\text { i odrębnym od innych } \\
\text { ludzi }\end{array}$ & 4,20 & 0,96 & 3,70 & 1,09 & 1,89 & n.i. \\
\hline Razem & 30,37 & 3,20 & 27,57 & 4,65 & 2,72 & 0,009 \\
\hline
\end{tabular}

Badani mężowie w kwestii świadomych osobistych przekonań bardzo różnią się między sobą. Na siedem rodzajów przekonań, w pięciu, mężowie transgresyjni uzyskali wyniki zdecydowanie wyższe niż mężowie zachowawczy. W pozostałych dwóch przekonaniach wyniki mężów transgresyjnych są nieco wyższe niż wyniki mężów o niskim poziomie transgresji, lecz nie są to różnice istotne statystycznie. Mężowie transgresyjni charakteryzują się większym poczuciem bycia osobą $-t(58)=3,08 ; p<0,003$, większym poczuciem własnego istnienia $-t(58)$ $=2,11 ; p<0,039$, silniejszym poczuciem sprawstwa podejmowanych przez siebie działań $-t(58)=2,38 ; p<0,021$, bardziej akceptują świat, łącznie z sobą $-t(58)=3,23 ; p<0,002$ i mają silniejsze poczucie, że przez całe życie są sobą $-t(58)=2,50 ; p<0,015$.

Tabela 10. Świadome osobiste przekonania mężów o wysokim i niskim poziomie transgresji

\begin{tabular}{|l|c|c|c|c|c|c|}
\hline \multirow{2}{*}{ Rodzaje przekonán } & \multicolumn{2}{|c|}{$\begin{array}{c}\text { Mężowie } \\
\text { transgresyjni } \\
\text { (n=30) }\end{array}$} & \multicolumn{2}{c|}{$\begin{array}{c}\text { Mężowie } \\
\text { zachowawczy } \\
(\mathbf{n = 3 0 )}\end{array}$} & \multicolumn{2}{c|}{$\begin{array}{c}\text { Istotność } \\
\text { różnic }\end{array}$} \\
\cline { 2 - 7 } & $\mathbf{M}$ & $\mathbf{S}$ & $\mathbf{M}$ & $\mathbf{s}$ & $\mathbf{t}$ & $\mathbf{p}<$ \\
\hline 1. Jestem osobą & 4,57 & 0,50 & 4,00 & 0,87 & 3,08 & 0,003 \\
\hline $\begin{array}{l}\text { 2. Poczucie własnego } \\
\text { istnienia }\end{array}$ & 4,47 & 0,63 & 4,10 & 0,71 & 2,11 & 0,039 \\
\hline $\begin{array}{l}\text { 3. Jestem sprawcą } \\
\text { podejmowanych przeze } \\
\text { mnie działań }\end{array}$ & 4,33 & 0,61 & 3,93 & 0,69 & 2,38 & 0,021 \\
\hline $\begin{array}{l}\text { 4. Akceptuję świat } \\
\text { w całości, łącznie } \\
\text { z własną osobą }\end{array}$ & 4,40 & 0,62 & 3,80 & 0,80 & 3,23 & 0,002 \\
\hline $\begin{array}{l}\text { 5. Poczucie, że jestem } \\
\text { niepodzielną całością }\end{array}$ & 4,10 & 0,99 & 3,70 & 1,02 & 1,54 & $n .1$. \\
\hline $\begin{array}{l}\text { 6. Poczucie, że przez całe } \\
\text { życie jestem sobą }\end{array}$ & 4,40 & 0,50 & 3,97 & 0,81 & 2,50 & 0,015 \\
\hline
\end{tabular}




\begin{tabular}{|l|c|c|c|c|c|c|}
\hline \multirow{2}{*}{ Rodzaje przekonán } & \multicolumn{2}{|c|}{$\begin{array}{c}\text { Mężowie } \\
\text { transgresyjni } \\
(\mathbf{n = 3 0 )}\end{array}$} & \multicolumn{2}{|c|}{$\begin{array}{c}\text { Mężowie } \\
\text { zachowawczy } \\
(\mathbf{n = 3 0 )}\end{array}$} & \multicolumn{2}{c|}{$\begin{array}{c}\text { Istotność } \\
\text { różnic }\end{array}$} \\
\cline { 2 - 7 } & $\mathbf{M}$ & $\mathbf{S}$ & $\mathbf{M}$ & $\mathbf{s}$ & $\mathbf{t}$ & $\mathbf{p}<$ \\
\hline $\begin{array}{l}\text { 7. Jestem różnym } \\
\text { i odrębnym od innych } \\
\text { ludzi }\end{array}$ & 4,17 & 1,12 & 3,73 & 1,14 & 1,48 & n.i. \\
\hline Razem & 30,43 & 3,42 & 27,23 & 4,27 & 3,20 & 0,002 \\
\hline
\end{tabular}

\section{Podsumowanie i dyskusja wyników}

Mąż i żona tworząc relację małżeńską stanowią diadę stykających się ze sobą, oddziaływujących na siebie osobowości, dwóch sieci złożonych z psychonów, charakteryzujących się między innymi określonym poziomem transgresji. Można przypuszczać, że wyższy poziom transgresji uwarunkowany jest większą mocą, siłą psychonów, które tworząc sieć są zdolne do samoorganizacji i samoistnych zmian, zwanych emergencją ${ }^{24}$. W odniesieniu do relacji małżeńskiej będzie to specyficzny układ wielu czynników dotyczących samych małżonków, jak i dynamicznych powiązań między nimi, które wpływają na jakość tworzonego przez nich związku ${ }^{25}$.

Transgresyjne żony i mężowie charakteryzują się bogatszą wiedzą na temat współmałżonka w zakresie sfery zadaniowej, co ułatwia przewidywanie i adekwatne oczekiwania odnośnie potencjalnych działań współmałżonka. Liczenie się ze współmałżonkiem, jego możliwościami w podejmowanym działaniu, daje mu większe szanse na poczucie wywiązywania się ze swoich obowiązków, oddalając destrukcyjne doświadczenie, że bierze na swoje barki zbyt wiele ${ }^{26}$. Potencjalnie chroni to przed pojawieniem się np. roszczeniowości odwetowej, która w konsekwencji prowadzi do obniżenia poczucia zadowolenia ze związku ${ }^{27}$. Mężowie transgresyjni charakteryzują się znacznie silniejszymi potrzebami poznawczymi i słabszymi potrzebami osobistymi, niż mężowie zachowawczy. Może to świadczyć o tym, że ich potrzeby

\footnotetext{
24 J. Kozielecki, Psychotransgresjonizm..., op. cit., s. 126-127.

A. Dakowicz, Powodzenie matżeństwa..., op. cit., s. 128-131.

M. Piasecka, Wiedza o sobie i wiedza o partnerze a ocena jakości matżeństwa, [w:] I. Janicka, T. Rostowska (red.), Psychologia $w$ stużbie rodziny, Łódź 2003, s. 78-88. ze zwiazku intymnego, „Studia Psychologiczne” 52(2014), s. 21-32.
} 
osobiste w związku małżeńskim są zaspokojone, a motywacja do działania wynika $\mathrm{z}$ realizacji potrzeb poznawczych ${ }^{28}$. Dynamika procesu motywacyjnego, związana z realizacją potrzeb poznawczych, na pewnym etapie łączy się ze zdobywaniem wiedzy dotyczącej otoczenia, co siłą rzeczy prowadzi do czasowego egocentryzmu ${ }^{29}$. W konsekwencji może dojść do psucia się struktury związku małżeńskiego ${ }^{30}$, co bliskie jest pojęciu transgresji destruktywnej ${ }^{31}$. Dalszy przebieg procesu motywacyjnego w oparciu o potrzeby poznawcze poprawia kontakt z otaczającą rzeczywistością na dłuższy czas i zwiększa jakość dialogu małżeńskiego ${ }^{32}$.

Pozytywne przesunięcie afektywne ${ }^{33}$, charakteryzujące mężów transgresyjnych, bardzo korzystnie wpływa na ich relacje w małżeństwie $^{34}$. Ciągle trwający proces kształtowania i modyfikacji postaw, szczególnie wobec najbliższych, w największym stopniu uzależniony jest od komponenty emocjonalnej ${ }^{35}$. Mężowie o większym pozytywnym przesunięciu afektywnym są w stanie częściej przyjąć wobec swojej żony całościową postawę pozytywną ${ }^{36}$, która wzmacnia w niej wiarę, że jest się kochanym przez współmałżonka ${ }^{37}$.

Wyższy poziom świadomych osobistych przekonań małżonków transgresyjnych stanowi wyraz ich własnej egzystencji i tożsamości ${ }^{38}$. Zarówno żony, jak i mężowie transgresyjni, mają silne przekonanie bycia sprawcą podejmowanych przez siebie działań, jak również akceptują świat w całości, łącznie ze sobą. Poczucie sensu podejmowanych działan, nierzadko wbrew pesymistycznym wizjom płynącym

$28 \quad$ S. Weber, Wrażliwy wojownik, Warszawa 2007.

J. Kozielecki, Psychotransgresjonizm..., op. cit., s. 45-47.

M. Tański, Kontrowersje wokót koncepcji transgresyjnej Józefa Kozieleckiego, „Studia Humanistyczne” 3(2005), s. 137-143.

J. Kozielecki, Psychotransgresjonizm..., op. cit., s. 48-49.

J. Baniak, Znaczenie dialogu w mał̇̇eństwie, „Małżeństwo i Rodzina” 1(2004), s. 25-28.

J. Kozielecki, Psychotransgresjonizm..., op. cit., s. 151.

J. Wortman, D. Wood, R. M. Furr, J. Fanciullo, P. D. Harms, The relations between actual similarity and experienced similarity, „Journal of Research in Personality" 49(2014), s. 31-46.

S. Mika, Psychologia społeczna, Warszawa 1987, s. 270.

B. Wojciszke, Psychologia społeczna, Warszawa 2011.

M. Chmielewska, Jakość związku matżeńskiego a uzależnienie interpersonalne, „Kwartalnik Naukowy Fides et Ratio” 1(2012), s. 90-113. 
z otoczenia, umożliwia osiąganie stawianych sobie przez małżonków celów. Tego typu postępowanie zbliżone jest do działania osób o aktywnej sferze noetycznej, co mocno łączy się z poczuciem sensu życia i zdrowiem psychicznym ${ }^{39}$.

\section{Zakończenie}

Przeprowadzona analiza i dokonana interpretacja wyników badań małżonków o wyższym i niższym poziomie transgresji wyraźnie charakteryzuje żony i mężów transgresyjnych jako osoby zintegrowane wewnętrznie, o dużym potencjale psychicznym, pozwalającym podejmować na swojej drodze różnego rodzaju zadania egzystencjalne, przez co ciągle poszerzają swoje kompetencje. Nieustanne budowanie w zmieniającej się rzeczywistości przez oboje małżonków satysfakcjonującej relacji interpersonalnej, ze względu na posiadane możliwości, daje zdecydowanie więcej szans osobom transgresyjnym niż zachowawczym. Aby lepiej zrozumieć dostrzeżone prawidłowości należałoby przeprowadzić dalsze badania i pogłębić ich interpretację. Kolejnym krokiem wzbogacającym charakterystykę psychologiczną małżonków o wysokim poziomie transgresji może być realizacja projektu badawczego na poziomie par małżeńskich o różnym stopniu transgresji. Biorąc pod uwagę skłonność kobiet do transgresji etycznej i rodzinnej, a mężczyzn do transgresji zawodowej i materialnej ${ }^{40}$, można spodziewać się odkrycia specyficznych zależności, które na bazie podejścia psychotransgresyjnego mogą otworzyć nową perspektywę w spojrzeniu na uwarunkowania powodzenia współczesnych związków małżeńskich.

Słowa kluczowe: psychotransgresjonizm, sieciowa teoria osobowości, małżeństwa transgresyjne i zachowawcze, powodzenie małżeństwa, ryzyko rozwodu.

$39 \quad$ K. Popielski, Noetyczny wymiar osobowości. Psychologiczna analiza poczucia sensu życia, Lublin 1994; P. Szczukiewicz, O pomaganiu i psychoterapeutach. Ksztattowanie się postaw wobec profesjonalnej pomocy psychologicznej, Lublin 2005; J. Różycka, K. Skrzypińska, Perspektywa noetyczna w psychologicznym funkcjonowaniu człowieka, „Roczniki Psychologiczne” t. XIV, nr 2(2011), s. 101-121.

40 S. Ślaski, Motywacyjno-osobowościowe wyznaczniki zachowań transgresyjnych i ochronnych, Warszawa 2012. 


\section{Bibliografia:}

1. Adamski F., Rodzina. Wymiar społeczno-kulturowy, Kraków 2002.

2. Aranowska E., Goszczyńska M. (red.), Człowiek wobec wyzwań i dylematów wspótczesności, Warszawa 2006.

3. Babbie E., Badania spoteczne w praktyce, Warszawa 2004.

4. Baniak J., Znaczenie dialogu w małżeństwie, „Małżeństwo i Rodzina” 1(2004).

5. Bedyńska S., Cypryańska M. (red.), Statystyczny drogowskaz 1. Praktyczne wprowadzenie do wnioskowania statystycznego, Warszawa 2013.

6. Błażek M., Rozwód jako sytuacja kryzysowa $w$ rodzinie, [w:] I. Janicka, H. Liberska (red.), Psychologia rodziny, Warszawa 2014.

7. Braun-Gałkowska M., Nie wszystkie kwiaty zakwitaja razem. Kilka myśli o starości, Lublin 2015.

8. Braun-Gałkowska M., Psychologia domowa, Lublin 2008.

9. Braun-Gałkowska M., Psychologiczna analiza systemów rodzinnych osób zadowolonych i niezadowolonych z matżeństwa, Lublin 1992.

10. Chmielewska M., Jakość związku matżeńskiego a uzależnienie interpersonalne, „Kwartalnik Naukowy Fides et Ratio” 1(2012).

11. Dakowicz A., Marital success from the perspective of Kozielecki's transgression model, „Studies in Logic, Grammar and Rhetoric. Cognitive Systems" 40(2015).

12. Dakowicz A., Potrzeby indywidualne matżonków zadowolonych i niezadowolonych ze swojego zwiazku, „Edukacja. Studia, badania, innowacje” 3(2011).

13. Dakowicz A., Powodzenie matżeństwa. Uwarunkowania psychologiczne w perspektywie transgresyjnego modelu Józefa Kozieleckiego, Białystok 2014.

14. Dakowicz A., Psychologiczna analiza matżonków o wysokim i niskim poziomie transgresji, [w:] T. Rostowska, A. Lewandowska-Walter (red.), Matżeństwo i rodzicielstwo a zdrowie, Toruń 2012, s. 79-101.

15. Dyczewski L., Małżeństwo i rodzina upragnionymi wartościami młodego pokolenia, [w:] L. Dyczewski (red.), Matżeństwo i rodzina w nowoczesnym społeczeństwie, Lublin 2007.

16. Dyczewski L., Wyobrażenia młodzieży o matżeństwie i rodzinie. Pomiędzy tradycja a nowoczesnościa, Lublin 2009.

17. Jabłoński D., Ostasz L., Zarys wiedzy o rodzinie, matżeństwie, kohabitacji i konkubinacie. Perspektywa antropologii kulturowej i ogólnej, Olsztyn 2001.

18. Jarymowicz M., Psychologia tożsamości, [w:] J. Strelau (red.), Psychologia. Podręcznik akademicki, t. 3, Gdańsk 2000.

19. Jeziorański M., Opozda D., Rynio A. (red.), Rodzina przestrzenia rozwoju osoby. Perspektywa pedagogiczna, Lublin 2012.

20. Kozielecki J., Psychotransgresjonizm. Nowy kierunek psychologii, Warszawa 2007.

21. Matczak A., Jaworowska A., Ciechanowicz A., Stańczak J., Bateria testów APIS-Z. Podręcznik, Warszawa 2006.

22. Mika S., Psychologia społeczna, Warszawa 1987.

23. Piasecka M., Wiedza o sobie i wiedza o partnerze a ocena jakości matżeństwa, [w:] I. Janicka, T. Rostowska (red.), Psychologia w stużbie rodziny, Łódź 2003. 
24. Popielski K., Noetyczny wymiar osobowości. Psychologiczna analiza poczucia sensu życia, Lublin 1994.

25. Reddin B., Testy dla meneḋ̇erów stawiających na efektywność, Warszawa 1993.

26. Rostowski J., Rostowska T., Matżenstwo i mitość. Kontekst psychologiczny i neuropsychologiczny, Warszawa 2014.

27. Różycka J., Skrzypińska K., Perspektywa noetyczna w psychologicznym funkcjonowaniu człowieka, ,Roczniki Psychologiczne” t. XIV, nr 2(2011).

28. S. Ślaski, Motywacyjno-osobowościowe wyznaczniki zachowań transgresyjnych i ochronnych, Warszawa 2012.

29. Studenski R., Skłonność do ryzyka a zachowania transgresyjne, [w:] M. Goszczyńska, R. Studenski (red.), Psychologia zachowań ryzykownych. Koncepcje, badania, praktyka, Warszawa 2006.

30. Szczukiewicz P., O pomaganiu i psychoterapeutach. Ksztattowanie się postaw wobec profesjonalnej pomocy psychologicznej, Lublin 2005.

31. Tański M., Kontrowersje wokót koncepcji transgresyjnej Józefa Kozieleckiego, „Studia Humanistyczne” 3(2005).

32. Weber S., Wrażliwy wojownik, Warszawa 2007.

33. Wojciszke B., Psychologia społeczna, Warszawa 2011.

34. Wortman J., Wood D., Furr R. M., Fanciullo J., Harms P. D., The relations between actual similarity and experienced similarity, „Journal of Research in Personality" 49(2014).

35. Żemojtel-Piotrowska M., Piotrowski J., Baran T., Roszczeniowość a satysfakcja ze zwiazku intymnego, „Studia Psychologiczne” 52(2014). 